\title{
Tilfelli mánaðarins: Nýburi með uppköst
}

\section{Arndís Auður Sigmarsdóttir læknir, Anna Gunnarsdóttir læknir}

Bréfaskipti: Anna Gunnarsdóttir annagunn@landspitali.is

\section{Tilfellio}

Stúlka fædd eftir tæplega 42 vikna eðlilega meðgöngu og fæðingu, vó 3440 gr. Barnabik hafði skilað sér stuttu eftir fæðingu og hægðir voru eðlilegar. Við 5 daga skoðun á spítala nefndu foreldrarnir kröftug skærgræn uppköst hjá stúlkunni heima og að hún væri löt við brjóstagjöf. Hún hafði lést um 300 gr, eða um tæp 9\% af

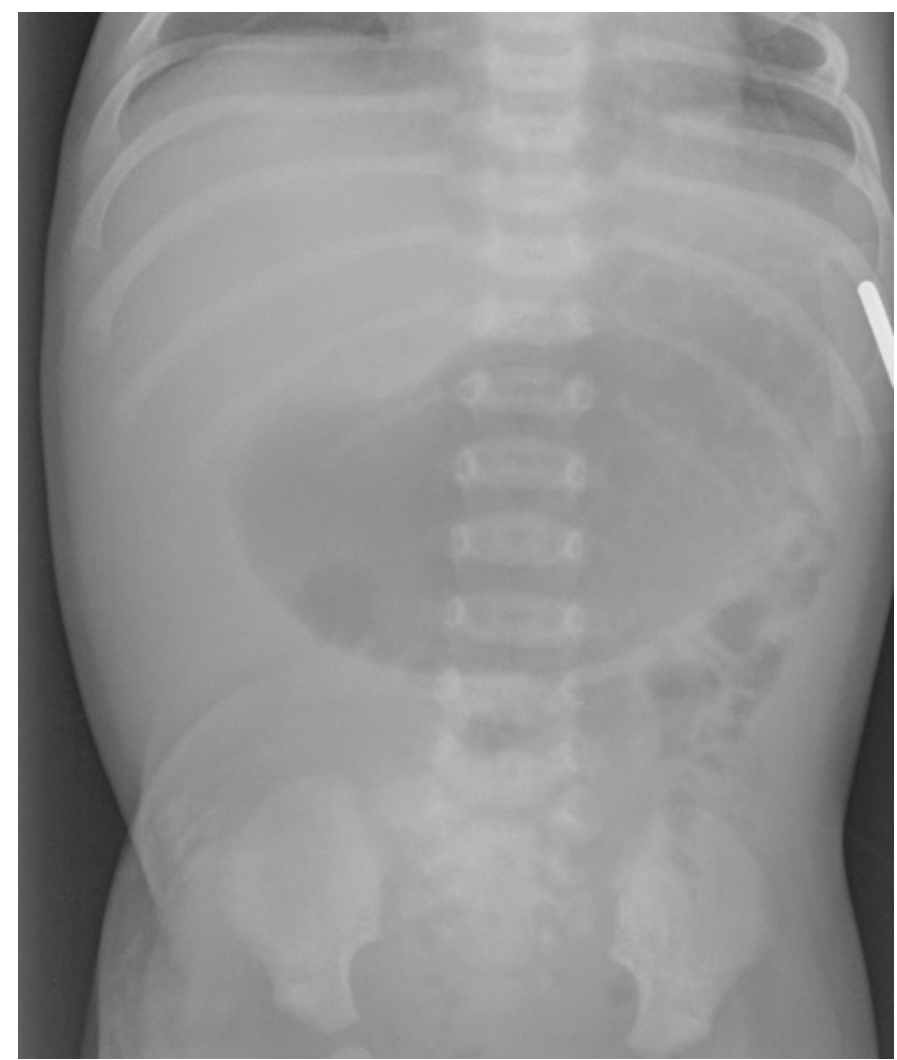

Mynd 1. Hefðbundin röntgenyfirlitsmynd af kvið. líkamspyngd sinni. Við skoðun var stúlkan ekki bráðveikindaleg að sjá, kviður mjúkur, ekki paninn og garnahljóð lágvær. Stúlkan kastaði ekki upp við komu. Fengin var yfirlitsmynd af kvið (mynd 1) og gegnumflæðimynd (passage) (mynd 2).

Hver er sjúkdómsgreiningin?

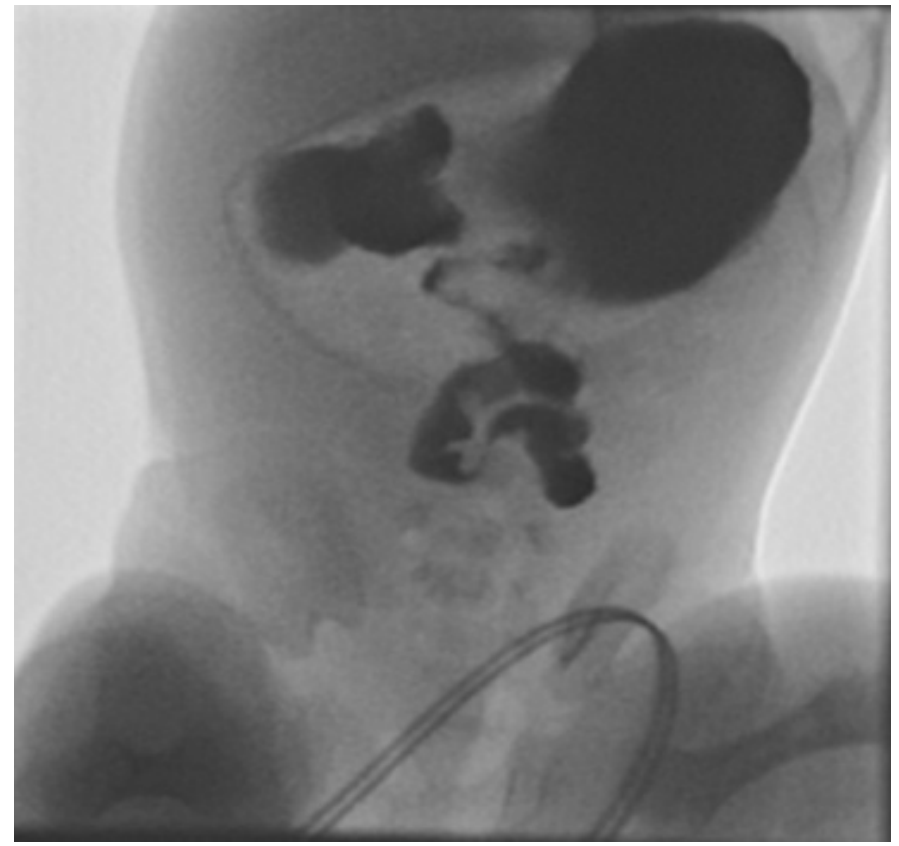

Mynd 2. Gegnumflæðimynd af efri hluta meltingarvegar. 


\section{Svar við tilfelli mánaðarins: Vansnúningur á görn}

Mynd 2 gefur greininguna sem er meðfæddur vansnúningur á görn. Við eðlilegan snúning garnar á fósturskeiði snýst görnin rangsælis um $270^{\circ} 1$ tveimur prepum ádur en hún dregst inn 1 kviðarhol og festist á viðeigandi stöðum. ${ }^{1}$ Truflun á pessum snúningi veldur óeðlilegri garnafestu í kviðarholi og áhætta á snúning um garnahengi (mesentery) eykst. Blindparmur (cecum) er ranglega staðsettur í efri hægri fjórðungi og tjóðraður við hægri hluta kviðveggjar og lifur með lífhimnuböndum, svokölluðum Ladd's böndum. ${ }^{1,2}$ Truflun á snúningi garnar getur verið mismikil, allt frá pví að ná einungis til ristils (truflun á seinni snúningi) yfir í að vera enginn snúningur (nonrotation).

Nýgengi vansnúnings á görn er í kringum 1 af hverjum 500 fæddum börnum en talið er að aðeins 12 . hvert barn með vansnúning fái einkenni (1/6000). ${ }^{3}$ Um helmingur barna með vansnúning fá einkenni fyrir eins mánaðar aldur og um $80 \%$ á fyrsta ári. ${ }^{4}$ Einkennin stafa af garnaflækju (volvulus) par sem görnin snýst um garnahengi og eru kviðverkir, væg pensla á kvið, dreifð preifieymsli með eða án lífhimnuertingar og gallituð uppköst. ${ }^{2,5}$ Hjá yngstu börnunum geta einu einkennin pó verið að barnið er slappt og með galllituð uppköst. Alvarlegasta einkennið er blóð í hægðum og merki um lífhimnuertingu sem bendir til blóðpurrðar eða garnadreps. Pá er um lífshættulegt ástand að ræða og mikilvægt að bregðast fljótt við með aðgerð. Eldri börnin hafa oft fengið endurtekin kviðverkjaköst, oftast með uppköstum, sem hafa gengið til baka af sjálfu sér. ${ }^{2,5}$

Kviðarholsyfirlit er yfirleitt eðlilegt pó par geti sést vökvaborð í garnalykkjum og pensla á maga (mynd 1). Besta rannsókn til greiningar á vansnúningi er gegnumflæðimynd á efri hluta meltingarvegar (mynd 2). 2,4,5 Pá er lega skeifugarnarinnar óeðlileg pannig að hún gengur beint niður hægra megin við hryggsúlu og fer ekki yfir miðlínu til vinstri eins og eðlilegt er. Ristilinnhelling með skuggaefni getur einnig sýnt vansnúning ef ristill liggur allur vinstra megin í kviðarholi með blindparm ofarlega hægra megin. Ómun og tölvusneiðmynd geta sýnt afbrigðilega afstöðu milli slagæðar og bláæðar garnahengis ( $a$. og v. mesenterica superior) par sem bláæðin liggur vinstra megin og/eða ofan við slagæðina. ${ }^{2-4}$ Sé um garnaflækju að ræða getur sést hvirfiltákn (whirlpool sign). ${ }^{4}$ 6,7 Tölvusneiðmyndataka hefur pó aldrei hlutverk í uppvinnslu á bráðveiku barni par sem grunur er um garnaflækju vegna vansnúnings á görn.

Kröftug og endurtekin uppköst hjá ungabörnum teljast óeðlileg og á að taka alvarlega, sér í lagi ef önnur einkenni, eins og hiti, verkir, pyngdartap eða lystarleysi, fylgja. Hjá ungabörnum eru helstu mismunagreiningarnar vélindabakflæði, prengsli á neðra magaopi (pylorus stenosis) og garnastopp. Liturinn á uppköstum segir mikið til um hvar prengslin geta verið.2, 5 Galllituð uppköst fylgja sjaldnast prengslum í magaopi né vélindabakflæði par sem meinsemdin er pá ofan gallganga. Galllituð uppköst koma til vegna garnastopps og teljast til bráðra einkenna. Algengustu ástæður garnastopps hjá ungabörnum eru garnaflækja vegna vansnúnings á görn, Hirschsprung's sjúkdómur, garnarsmokkun (intussusception) eða garnalokun (atresia).

Við Hirschsprung's sjúkdóm eru helstu einkennin galllituð uppköst, paninn kviður og hægðatregða. ${ }^{2,}{ }^{5}$ Stúlkan í tilfellinu hafði skilað barnabiki og hafði eðlilegar hægðir.

Garnasmokkun er algengasta orsök garnastopps hjá börnum á aldrinum 6-36 mánaða. Dæmigerðir eru skyndilegir og kveisukenndir kviðverkir. Uppköstin eru eðlilega útlítandi í byrjun en verða síðan galllituð pegar stíflueinkennin aukast., ${ }^{2,5}$

Meðfædd garnalokun eða prengsli (stenosis) er helsta mismunagreiningin ef galllituð uppköst koma fram strax eftir fæðingu. Par sést alltaf víkkun á görninni fyrir ofan lokunina á yfirlitsmynd. Einkenni geta pó komið seinna fram ef lokunin er í fjærenda garnarinnar eða ef um prengsli er að ræða.

Meðferð vansnúnings á görn er svokölluð Ladd's-aðgerð til að minnka líkur á garnaflækju. Eru Ladd's-böndin pá tekin sundur, stofn garnahengis víkkaður, botnlangi fjarlægður og görnin sett í stöðu eins og enginn snúningur hefði orðið. Liggur smágirnið pá hægra megin í kviðarholi og ristillinn vinstra megin. Greinist vansnúningur garnar fyrir tilviljun hjá einkennalausum einstaklingum er oftast mælt með pví að gera fyrirbyggjandi skurðaðgerð vegna hættu á garnaflækju. ${ }^{3,4}$

Stúlkan sem um ræðir gekkst undir Ladd's-aðgerð með góðum árangri, hún var útskrifuð viku eftir aðgerð og hefur verið einkennalaus í ár.

\section{Heimildir}

1. Colombani P, Dudgeon, DL, Beaver BL, Vanderhoof JA. Rudolph's Pediatrics. 19th ed. Appleton \& Lange, East Norwalk, Connecticut 1991.

2. Stevens M, Henretig, FM. Textbook of Pediatric Emergency Medicine. 6th ed. Lippincott Williams \& Wilkins, Philadelphia 2010.

3. Dilley AV, Pereira J, Shi EC, Adams S, Kern IB, Currie B, et al. The radiologist says malrotation: does the surgeon operate? Pediatr Surg Int 2000; 16: 45-9.

4. Millar AJ, Rode $\mathrm{H}$, Cywes S. Malrotation and volvulus in infancy and childhood. Semin Pediatr Surg 2003; 12: 229-36.

5. Barksdale EJ. Atlas of Pediatric Physical Diagnosis. 5th ed. Mosby Elsevier, Philadelphia 2007.

6. Dufour D, Delaet MH, Dassonville M, Cadranel S, Perlmutter N. Midgut malrotation, the reliability of sonographic diagnosis. Pediatr Radiol 1992; 22: 21-3.

7. Pracros JP, Sann L, Genin G, Tran-Minh VA, Morin de Finfe CH, Foray P, et al. Ultrasound diagnosis of midgut volvulus: the „whirlpool" sign. Pediatr Radiol 1992; 22: 18-20.

Case of the month: Neonatal vomiting Diagnosis: Intestinal malrotation

Sigmarsdottir AA, Gunnarsdottir A annagunn@landspitali.is 